\title{
MATURITY AND QUALITY OF APPLE FRUIT DURINIG THE HARVEST PERIOD AT APPLE INDUSTRY ${ }^{1}$
}

\author{
MARCOS WESTPHAL GONÇALVES², LUIZ CARLOS ARGENTA³, \\ MARIUCCIA SCHLICHTING DE MARTIN ${ }^{4}$
}

ABSTRACT - A database of maturity and quality indices was built by analysis of 62,807 samples of 100 'Gala' apples and 29,053 samples of 100 'Fuji' apples at harvest, over 11 years (2005-2015) in an apple industry warehouse. Apple fruit were harvested in Fraiburgo (SC), São Joaquim (SC) and Vacaria (RS). Data on firmness, starch index (SI), soluble solid content (SS), titratable acidity (TA), size and grades (external appearance) of apple fruit were submitted to linear and nonlinear regression analyses. Each fruit was graded by analysis of external qualities (color and surface blemishes) following Brazilian legal standards. At apples industry, the harvest period extended from $3^{\text {rd }}$ to $15^{\text {th }}$ week of the year for 'Gala' and from $10^{\text {th }}$ to $22^{\text {nd }}$ week of the year for 'Fuji' apples, although approximately $70 \%$ of total production for 'Gala' and 'Fuji' apples was harvested in a period of 4 and 6 weeks, respectively. Average maturity of 11 years varied from the $1^{\text {st }}$ to the last week of harvest as follows: 'Gala' apples: 17.9 to 14.2 pounds (firmness), 4.0 to 6.1 (SI), 12.2 to $13.1 \%$ (SS) and 5.7 to 3.9 meq $100 \mathrm{~mL}^{-1}$ (TA). 'Fuji' apples: 17.1 to 14.3 pounds (firmness), 3.9 to 6.4 (SI), 12.9 to $14.4 \%$ (SS), 6.2 to 3.8 meq $100 \mathrm{~mL}^{-1}$ (TA). Approximately $48 \%$ of 'Gala' samples and $45 \%$ of 'Fuji' samples had firmness higher than 17 and 16 pounds, respectively, intended for long term storage, while 6\% of 'Gala' samples and $8.5 \%$ of 'Fuji' samples had firmness lower than 14 pounds, intended for marketing shortly after harvest. The frequency of apple samples graded as Extra, Cat1, Cat2, Cat3 and out of category were $6 \%, 32 \%, 34 \%$ and $6 \%$ for 'Gala' apples and $5 \%, 39 \%, 33 \%, 18 \%, 5 \%$ for 'Fuji' apples.

Index terms: Malus domestica, harvest date, category, pulp firmness.

\section{MATURAÇÃO E QUALIDADE DE MAÇÃS NO PERÍODO DE COLHEITA, EM NÍVEL COMERCIAL}

RESUMO - O objetivo deste trabalho foi formar um banco de dados de índices de maturação e qualidade pela análise de 62807 amostras de 100 maçãs 'Gala' e 29053 amostras de 100 maçãs 'Fuji', na colheita, constituído ao longo de 11 anos (2005 a 2015), em uma empresa comercial. As maçãs foram colhidas em Fraiburgo (SC), São Joaquim (SC) e Vacaria (RS). Os dados de firmeza de polpa, índice de amido (IA), teor de sólidos solúveis (SS), acidez titulável (AT), tamanho e categoria das maçãs foram submetidos a análises de regressões lineares e não lineares. A categoria de cada fruto foi determinada pela análise da qualidade externa (coloração e danos) segundo normas legais Brasileiras. O período de colheita comercial se estendeu da $3^{\mathrm{a}}$ à $15^{\mathrm{a}}$ semana do ano para a 'Gala' e da $10^{\mathrm{a}}$ a $22^{\mathrm{a}}$ semana do ano para a 'Fuji', embora aproximadamente $70 \%$ da produção de 'Gala' e 'Fuji' foram colhidas num período de 4 e 6 semanas, respectivamente. Os índices de maturação dos 11 anos variaram da primeira à última semana de colheita, sendo que, para maçãs 'Gala', foram de 17,9 a 14,2 lb (Firmeza), 4,0 a 6,1 (IA), 12,2 a 13,1\% (SS) e 5,7 a 3,9 meq $100 \mathrm{~mL}^{-1}$ (AT), enquanto que para maçãs 'Fuji' foram de 17,1 a 14,3 lb (Firmeza), 3,9 a 6,4 (IA), 12,9 a 14,4\% (SS) e 6,2 a 3,8 meq $100 \mathrm{~mL}^{-1}$ (AT). Aproximadamente $48 \%$ das amostras de 'Gala' e $45 \%$ das amostras de Fuji apresentaram firmeza da polpa superior a $17 \mathrm{lb}$ e $16 \mathrm{lb}$, respectivamente, adequadas para longos períodos de armazenagem, enquato 6\% das amostras de 'Gala' e 8,5\% das amostras de 'Fuji' apresentaram firmeza da polpa inferior a $14 \mathrm{lb}$, indicadas à comercialização imediata após a colheita. As frequências de amostras de maçãs com qualidade Extra, Cat1, Cat2, Cat3 e fora de Categoria foram de 6\%, 32\%, 34\%, 22\% e 6\%, respectivamente, para 'Gala' e 5\%, 39\%, 33\%, 18\%, 5\% para 'Fuji'.

Termos para indexação: Malus domestica, ponto de colheita, categoria, firmeza de polpa.

\footnotetext{
${ }^{1}$ (Paper 104-16). Received August 15, 2016. March 28, 2017.

${ }^{2}$ Agronomist, Fischer S/A Agroindústria. Rod. SC 453, km 24, Caixa Postal 131, CEP 89580-000, Fraiburgo-SC. Email: mgoncalves@ fischerfrutas.com

${ }^{3}$ Agronomist, PhD, Researcher at Estação Experimental de Caçador, EPAGRI. Rua Abílio Franco, 1500, CEP 89500-000, Caçador-SC. Corresponding author. Email: argenta@epagri.sc.gov.br

${ }^{4}$ Agronomist, PhD, Researcher at Estação Experimental de Caçador, EPAGRI. Rua Abílio Franco, 1500, CEP 89500-000, CaçadorSC. Email: mariucciamartin@epagri.sc.gov.br
} 


\section{INTRODUCTION}

The maturity at harvest is one of the factors that most affects the quality of apples at harvest and after storage. The quality of apples (Malus domestica Borkhausen) can be negatively affected, both by excessive early and late harvest, especially when fruits are intended for long-term storage. In addition, the harvesting time also influences important characteristics that define the commercial value of fruits such as size and peel color (PLOTTO et al., 1995, STANGER et al., 2013, SCOLARO et al., 2015).

The disadvantages of early apple harvesting include reduced yield due to smaller fruit size, greater susceptibility to post-harvest water loss and even the inability to produce sensory trait required by the consumer, especially due to the low sugar content and low production of aromatic compounds (DE CASTRO et al., 2007, STANGER et al., 2013). Moreover, even though they are more tolerant to handling at harvest, fruits harvested early are more susceptible to superficial scald and bitter pit (LURIE; WATKINS, 2012; JEMRIĆ et al., 2016). In contrast, fruit harvested late have storage potential compromised by being more susceptible to rot, mechanical damage, $\mathrm{CO}_{2}$ injury and senescence (ARGENTA, 2002). The harvest of fruits after the optimum maturity stage also favors the occurrence of low sensorial quality due to the loss of crispness and juiciness and excessively high sugar / acidity ratio (WATKINS et al., 2005; STANGER et al., 2013).

Maturity indices for the optimum harvest time of 'Gala', 'Fuji' and 'Daiane' apples produced in southern Brazil have been determined by several studies (ARGENTA and MONDARDO, 1994; ARGENTA et al., 1995; STANGER et al., 2013) and have been used to guide the beginning of the harvest time and for segregation and targeting lots of apples for different marketing time and length of storage. Some difficulties in harvesting apples at appropriate maturation stage have been pointed out by producers and industry. It is noteworthy that more than $95 \%$ of apples harvested are of only two cultivars, 'Gala' and 'Fuji' (PÉRÈS et al., 2009), the occurrence of unfavorable climatic conditions, particularly precipitation in the harvest time and insufficient availability of labor and infrastructure for harvesting, reception and handling at warehouse. The planting of apple trees in regions with different microclimates and the use of growth regulators to manage the dormancy release, flowering time and fruit maturation on the tree have been used to schedule the harvest time and to reduce the risk of harvesting immature and overripe apples (HAWERROTH et al., 2011; PETRI et al., 2011; SCOLARO et al., 2015).

The commercial harvest time of apple fruit is mainly determined by quality indices such as red color, fruit size and maturity indices such as firmness, soluble solids content (SS), starch index and background skin color (ARGENTA, 2002; WATKINS et al., 2005). Maturity indices have been widely used to monitor the maturation of apple fruit in commercial orchards and to estimate the harvest time of fruit (ARGENTA et al., 2010). However, it is unknown how much of the apples produced by the apples industry of Brazil are harvested at optimum maturity according to their post-harvest destination and consumer demands for quality.

The aim of this work was to analyze the maturity and quality indices of 'Gala' and 'Fuji' apple fruit throughout the harvest period and the relative amount of apples harvested with maturation indices suitable for long, medium and short storage periods, at Brazilian apple industry.

\section{MATERIAL AND METHODS}

A database of maturity and quality of apples from a warehouse located in Fraiburgo, SC, was built by analyzing 62,807 samples of apple fruit of cultivar Gala and their colored strains ('Gala') and 29,053 samples of apple fruit of cultivar Fuji and their colored strains ('Fuji'), between 2005 and 2015. The apples analyzed apple fruit were harvested in commercial orchards from Fraiburgo $(60 \%$ of samples) and São Joaquim (30\% of samples), in Santa Catarina, and Vacaria (10\% of sample), in Rio Grande do Sul. The number of samples analyzed varied among years and was proportional to the variation of the total amount of apples stored (90 to 110 thousand metric tons per year) in the warehouse. The annual average number of assessed samples was 5,700 of 'Gala' and 2,650 of 'Fuji'. .

Each sample was composed of 100 apples from the same orchard, harvest date and cultivar, randomly collected from one truck load, at arrival in the warehouse, $4 \mathrm{~h}$ to $48 \mathrm{~h}$ after harvest.. Each truck loads was composed of 18 to 60 bins, with each bin containing approximately $380 \mathrm{~kg}$ of 'Gala' apples or $390 \mathrm{~kg}$ of 'Fuji' apples. Apple samples were identified by the sample number, cultivar name, harvest date, origin (region and orchard) and number of bins represented by the sample and then analyzed. The amount of apple bins received in the warehouse was recorded and used to indicates the amount of apples 
harvested per week (Figures $1 \mathrm{~F}$ and $2 \mathrm{~F}$ ).

Fruits were assessed for external quality (grades), size and maturity indices. Each fruit was graded by analysis of external qualities (color and surface blemishes). The percentage of reddish color was visually determined by the relationship between the surface area of reddish-colored fruits and the total surface area of fruits. Surface blemishes were those produced by the following factors: 1) Physiological, such as russeting, sunburn, peduncle crack, bitter pit, among others; 2) Phytopathological, such as scab and Glomerella stain; 3) Damage caused by insects and; 4) Abiotic (physical) such as hail, frost, bruising. Based on the analysis of the appearance, each fruit was classified in one of the following grades (categories of quality) : Extra, Cat1, Cat2, Cat 3 and out of category. The grading was performed according to the IN-05 standard grade established and regulated by the Ministry of Agriculture, Livestock and Supply (BRASIL, 2006). Out of category fruits were further subdivided into two groups: nondeveloping out of category (NDOC) and developing out of category (DOC). Lesions caused by hail, frost, scab, etc. were considered NDOC, while rot, bitter pit, senescence and phytotoxicity were considered DOC, whose severity could evolve in the post-harvest period. The classification of each fruit in a category of aesthetic quality allowed determining the frequency (\%) of fruits in each category for each sample of 100 fruits analyzed.

The size of fruits was analyzed by the determination of their biomass in digital electronic scale. Each fruit was classified into a size class according to norms of the Ministry of Agriculture Livestock and Supply (BRASIL, 2006). Size classes refer to the number of apples on a given fresh biomass scale $(\mathrm{g})$ required to produce a box containing $18 \mathrm{~kg}$ of apples.

The maturation of apples was analyzed by firmness, starch index, soluble solids (SS) and titratable acidity (TA) in a sub-sample of five apples with average weight of approximately 130 and 140 $\mathrm{g}$, selected from the main sample of 100 apples. Firmness and starch index measurements were performed for each fruit of the subsample while SS and TA measurements were performed in a single sample of juice extracted from the five fruits. The firmness analysis was performed at two opposite points on the surface of each fruit in the equatorial region, where the skin was previously removed, with the aid of an analogue penetrometer with 11 $\mathrm{mm}$ diameter tip, mounted on a platform bench for manual testing. The starch index was evaluated at harvest using scale from 1 to 9 , in which index 1 (cross-section of the pulp stained by the iodinestarch complex) indicates high starch content and immature fruit, and index 9 (cross-section of the pulp not stained by the iodine-starch complex) indicates starch content close to zero and ripened fruit. Titratable acidity (TA, meq $100 \mathrm{~mL}^{-1}$ ) was determined in a sample of $10 \mathrm{~mL}$ of juice diluted in $90 \mathrm{~mL}$ of distilled water and titrated with $0.1 \mathrm{~N} \mathrm{NaOH}$ solution using phenolphthalein as $\mathrm{pH}$ indicator. The SS content was determined in fruit juice using an analog refractometer (Atago ${ }^{\circledR}$, Tokyo, Japan).

The variation in the maturation indices and quality of apples as a function of the harvest week was adjusted to linear and non-linear models by means of regression analysis using mean data of the 11 years using the SigmaPlot 11.2 statistical software (SYSTAT SOFTWARE, 2011). The standard deviation were determined using mean data of each of the 11 years $(n=11)$. The harvest week refers to week of the year. Thus, the week 3 means the third week of the year. Frequency analyzes of samples at different scale of maturity indices and quality grade were performed using data from each sample of 100 apples from the 11-year data set; $n=62,807$ samples for 'Gala' apples; $\mathrm{n}=29,053$ samples for 'Fuji' apples. The frequencies of samples according to the fruit firmness, starch index and grades were adjusted to Gaussian equations using the software mentioned above.

\section{RESULTS AND DISCUSSION}

The harvest of 'Gala' apple fruit began in the third week of the year (mid January) and lasted until the $14^{\text {th }}$ week of the year (late March) (Figure $1 \mathrm{~F})$. A very clear harvest peak was observed for this cultivar at the $8^{\text {th }}$ week of the year, when was harvested approximately $21 \%$ of the total volume of apples received in the warehouse. The harvest of 'Fuji' in the 2005 to 2015 season was carried out over a period of 13 weeks between the $10^{\text {th }}$ and $22^{\text {nd }}$ weeks of the year (Figure $2 \mathrm{~F}$ ), which usually correspond to the first week of March and the last week of May, respectively.

The number of bins received at warehouse (Figures $1 \mathrm{~F}$ and $2 \mathrm{~F}$ )shows that, of the total number of apples harvested, approximately $68 \%$ were 'Gala' and $32 \%$ 'Fuji', this proportion being similar to the proportion of national 'Gala' and 'Fuji' production (PÉRÈS, 2009). Despite the higher volume of 'Gala' production, the harvest of this cultivar was more concentrated and faster than the harvest of 'Fuji' apples. Data on amount of fruit harvested weekly 
have shown that approximately $72 \%$ of 'Gala' apples are harvested at a four-week interval between the $6^{\text {th }}$ and $9^{\text {th }}$ weeks of the year, while approximately $73 \%$ of 'Fuji' apples are harvested at an interval of six weeks, between the $12^{\text {th }}$ and $17^{\text {th }}$ weeks of the year. Several reasons may explain why harvesting 'Gala' apples is more concentrated and faster than 'Fuji' apples, among which: 1) The maturation of 'Gala' apples on the tree is faster than that of 'Fuji' apples (ARGENTA, 1993; ARGENTA et al., 1995; PLOTTO et al., 1995). For this reason, a greater number of workers are usually hired to make the harvest of 'Gala' apples faster. 2) The volume of 'Gala' apples intended for long-term storage and export is higher than for 'Fuji' apples, being related to the higher production volume of 'Gala' apples; 3) 'Gala' apples have a lower storage potential than 'Fuji' apples (PLOTTO et al., 1995; ARGENTA, 2002), so a higher percentage of 'Gala' apples should be harvested with appropriate maturation indices to allow storage for medium and long periods; 4) Often, there is less availability of bins, transport and structure, storage chambers and even labor during the 'Fuji' harvesting period. In some cases, 'Fuji' harvesting depends on the release of storage space occupied by 'Gala' apples, as they are sorted, packaged and marketed.

The present study shows that at apple industry, the harvesting periods of 'Gala' and 'Fuji' apples extend for 12 and 13 weeks, respectively (Figures $1 \mathrm{~F}$ and $2 \mathrm{~F}$ ), being much longer than those experimentally indicated, even for apples produced in other countries (PLOTTO et al., 1995; SCOLARO et al., 2015). This greater extension of the commercial harvest period occurs because several technical means of orchard management are adopted to schedule the harvest of 'Gala' and 'Fuji' apples in Brazil. This technique is particularly important in the country, since approximately $95 \%$ of the apple production is concentrated in these two cultivars (PÉRÈS, 2009). Schedule of harvest prevents crop losses due to pre-harvest drop and / or post-harvest deterioration associated with the harvesting of overripe apples, and reduces harvesting costs (HAWERROTH et al., 2011).

In Brazil the management of harvest time involves the planting of orchards at different altitudes and microclimates, the management of the dormancy release of flowering buds at different time by the use of growth regulators and hasten or delay of apple maturity on the tree by the use of growth regulators. In addition, the planting of new 'Gala' and 'Fuji' strains that present precocious and more intense accumulation of red pigments in the skin have favored the anticipation of the harvesting period.

During the harvest period, there was a clear evolution of apple fruit maturation on the tree, characterized by reduction of firmness, starch content (increase of starch index) and TA, and an increase of SS content, as expected and already experimentally demonstrated for 'Gala' and 'Fuji' apples produced in Brazil (ARGENTA, 1993; ARGENTA, MONDARDO, 1994; ARGENTA et al., 1995; ARGENTA et al., 2010; SCOLARO et al., 2015).

Although the reduction in firmness as a function of the week of harvest was adjusted to sigmoid models for periods of 13 harvest weeks, there was a linear reduction in firmness between the $6^{\text {th }}$ and $12^{\text {th }}$ week of harvest for 'Gala' apples (Figure 1) and between 13 and 18 weeks for 'Fuji' apples (Figure 2). In these periods, firmness loss rates were 0.4 and 0.35 pounds per week for 'Gala' and 'Fuji' apples, respectively. However, weekly monitoring of maturation of 'Gala' apples from one same orchard demonstrates that the weekly firmness loss rate is 1.3 pounds (mean of 10 years) (ARGENTA et al., 1995), although it may vary from 0.95 to 1.4 pounds, depending on the orchard (ARGENTA, 1993; ARGENTA; MONDARDO, 1994). These same studies point out that the weekly firmness loss rate of 'Fuji' apples is 0.8 pounds (average of 10 years), although it can vary from 0.7 to 1.0 pounds, depending on the orchard.

The variation of the starch index of 'Gala' apples as a function of the commercial harvest week was adjusted to a sigmoid model, presenting mean values of 4.0 in the first weeks of harvest, 5.0 at harvest peak (week 8) and 6.3 in the last weeks of harvest (Figure 1). The starch index increased linearly in 'Fuji' apples throughout the harvest period, from an average value of 3.9 in the first harvest week to 6.4 in the last harvest week (Figure 2). The weekly increase in the starch index was 0.25 for 'Gala' apples in the linear increase phase (between the $4^{\text {th }}$ and $13^{\text {th }}$ week) and 0.22 for 'Fuji' apples. These starch index change rates over the commercial harvesting period are also lower than those described by Argenta (1993) and Argenta et al. (1995). According to these authors, the weekly increase in starch index is from 0.9 to 1.4 for 'Gala' apples and from 0.85 to 1.2 for 'Fuji' apples, depending on the region.

Increases in SS content in apples of both cultivars as a function of the harvest period were also adjusted to sigmoid models, which demonstrate a slow increase in SS content in the first and last weeks of the commercial harvest period. In 'Fuji' apples, the highest increase in SS content occurred between 
the $3^{\text {rd }}$ and the $6^{\text {th }}$ week of harvest. As observed for firmness and starch index, the variation of the mean SS levels between the beginning and the end of the commercial harvest period was lower than that demonstrated in previous experimental studies.

The rates of change in the maturity indices described in the present study are lower than those described in literature because the former reflect the maturity evolution of apples from different orchards and regions often harvested in one to three picking times. The second ones reflect the maturity evolution of apples from previously marked apple trees of one orchard block, weekly harvested along 5 to 6 weeks. These results show that the ways adopted by the growers to schedule the harvest of apples have been efficient.

The TA of apples of both cultivars decreased linearly over the commercial harvest period and the weekly loss rates $\left(0.15 \mathrm{meq} 100 \mathrm{~mL}^{-1}\right.$ for 'Gala' apples and $0.20 \mathrm{meq} 100 \mathrm{~mL}^{-1}$ for 'Fuji' apples) are similar to those experimentally observed, when apples of different weeks of harvest were harvested from the same orchard (ARGENTA, MONDARDO, 1994; ARGENTA et al., 1995).

Firmness is one of the most important quality traits of apples and therefore obtaining and maintaining high firmness from the orchard to the consumer is one of the biggest challenges in industry. In general, apples with high firmness at harvest will have greater firmness after storage, or could be stored longer. Argenta and Mondardo (1994), demonstrated that the minimum firmness at harvest of 'Gala' apples for long-term storage period is 17 pounds. Thus, it could be inferred that until approximately the $7^{\text {th }}$ week of the year, 'Gala' apples had adequate average firmness for prolonged storage, and from the $7^{\text {th }}$ week, apples would have adequate firmness for quick marketing or medium and short storage. Studies have indicated that apples with less than 12 pounds of firmness are considered mealy, with poor juiceness and crispness, and are usually rejected by consumers (HARKER et al., 2002).

Approximately $46 \%$ of 'Gala' apple fruit samples and $44 \%$ of 'Fuji' apple fruit samples showed firmness greater than 17 and 16 pounds, respectively (Figure 3), which have storage potential for long periods, according to Argenta and Mondardo (1994) and Argenta et al. (1995). In addition, 38\% of 'Gala' and $47 \%$ of 'Fuji' apple fruit samples had firmness from 15 to 17 pounds and 14 to 16 pounds, respectively, with storage potential for medium periods ( 3 to 5 months). On the other hand, $6.2 \%$ of 'Gala' apples and $2.3 \%$ of 'Fuji' apples showed firmness lower than 14 pounds and 13 pounds, respectively, and were therefore indicated for immediate marketing after harvest. Argenta and Mondardo (1994) and Argenta et al. (1995) suggest that the starch index of apples is between 3 and 5 for 'Gala' apples, and between 4 and 6 for 'Fuji' apples when intended for long storage periods. In the present study, the frequency of 'Gala' and 'Fuji' apples with starch index between 3 and 5 and between 4 and 6 were $37 \%$ and $56 \%$, respectively (Figure 3 ).

The preference of consumers for apples is positively correlated with the SS content, with rejection of apples with SS levels less than 12\% (HARKER et al., 2002; 2008). Thus, according to these authors, the average SS levels were higher than those referenced for good consumption patterns from the first week of harvest, for both cultivars.

It was not possible to identify a tendency of increase or reduction in the size of fruits during the period of commercial harvest, for both cultivars (Figures 1 and 2). Studies have shown that apples continue to grow during the ripening on the tree (STANGER et al., 2013). However, the present work shows that there is no trend of continuous increase in size (reduction of class size) throughout the harvest period of apple industry. It should be emphasized that the data presented in this study do not represent a growth and development curve of fruits of the same plant or orchard, but the evolution of quality (e.g., size) and maturation as a function of the week of harvest of apples from different orchards and regions.

The average frequency of apple fruit graded as Extra, Cat1, Cat2, Cat3, NDOC (non-developing out of category) and DOC (developing out of category) was, respectively, $6 \%, 31.5 \%, 34.4 \%$, $22 \%, 5.6 \%$ and $0.7 \%$ for 'Gala' and $4.6 \%, 38.4 \%$, $33.6 \%, 18.6 \%, 4.3 \%$, and $0.6 \%$ for 'Fuji' (Figure 4 ). Thus, the production of apples of the two highest quality grades and commercial value (Extra and Cat1) were approximately $37 \%$ for 'Gala' apples and $43 \%$ for 'Fuji' apples. The grade of apples, as well as the size, is responsible for large differences in revenue for both producer and packer. Unfavorable climatic conditions are among the main factors that make it difficult to increase the production of apples of higher standards of quality, highlighting the high incidence of damage caused by hail rains, russeting and rot, which are associated with high precipitation and relative humidity during the development of apples and due to reddish color deficiency, especially in years with high nocturnal temperatures during the summer. On the other hand, the continued expansion in the production of 'Gala' and 'Fuji' colored strains may allow increased production of apples of higher grades in the next years. 


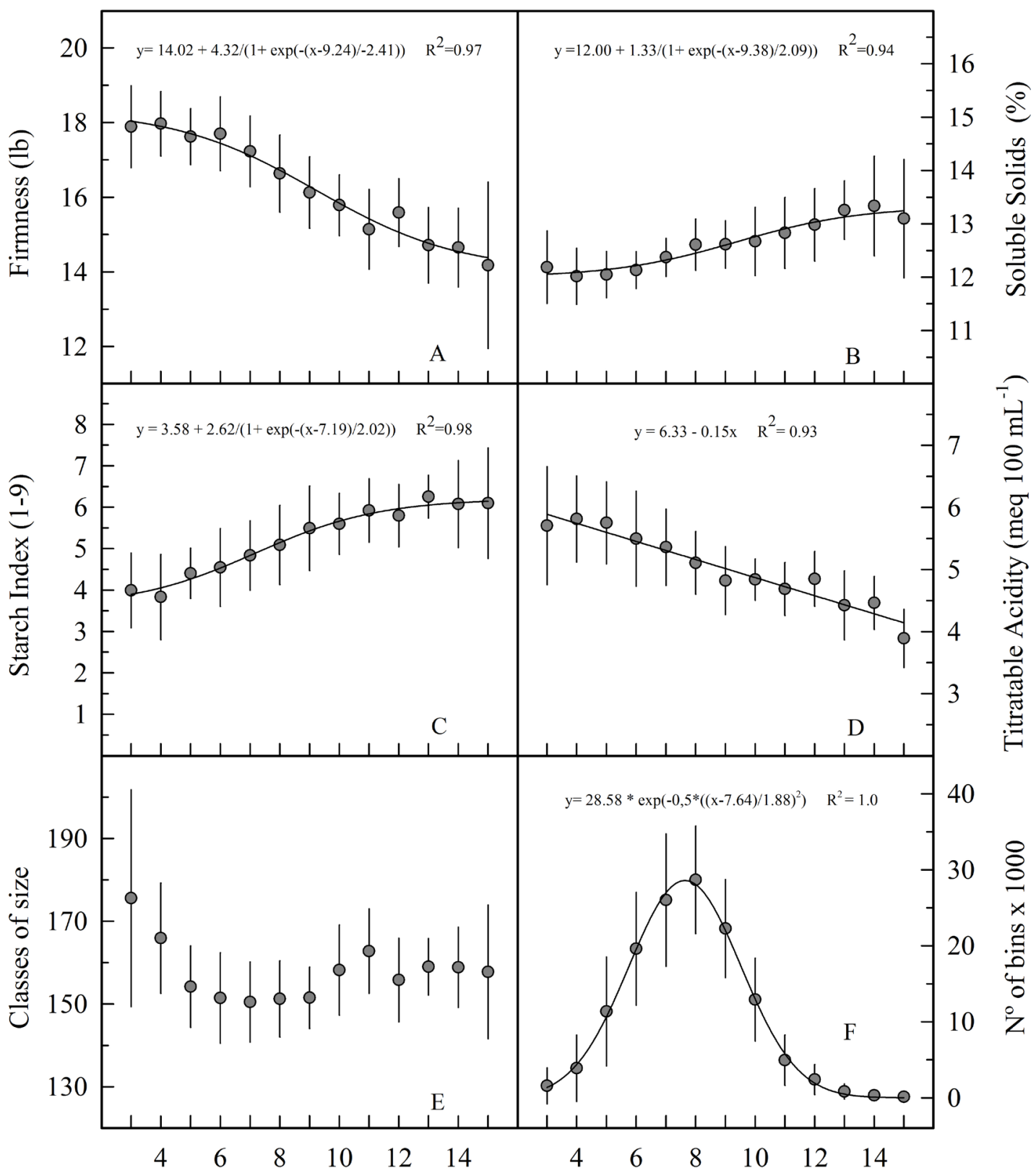

Harvest week of the year

FIGURE 1 - Firmness, soluble solids content, starch index, titratable acidity, class of fruit size and amount (number of bins) of 'Gala' apple fruit received at warehouse as a function of harvest week of the year. The week 4 in the graphic means the fourth week of the year. Data represent averages of 11 years $(n=11)$. Vertical bars indicate the standard deviation among years. 


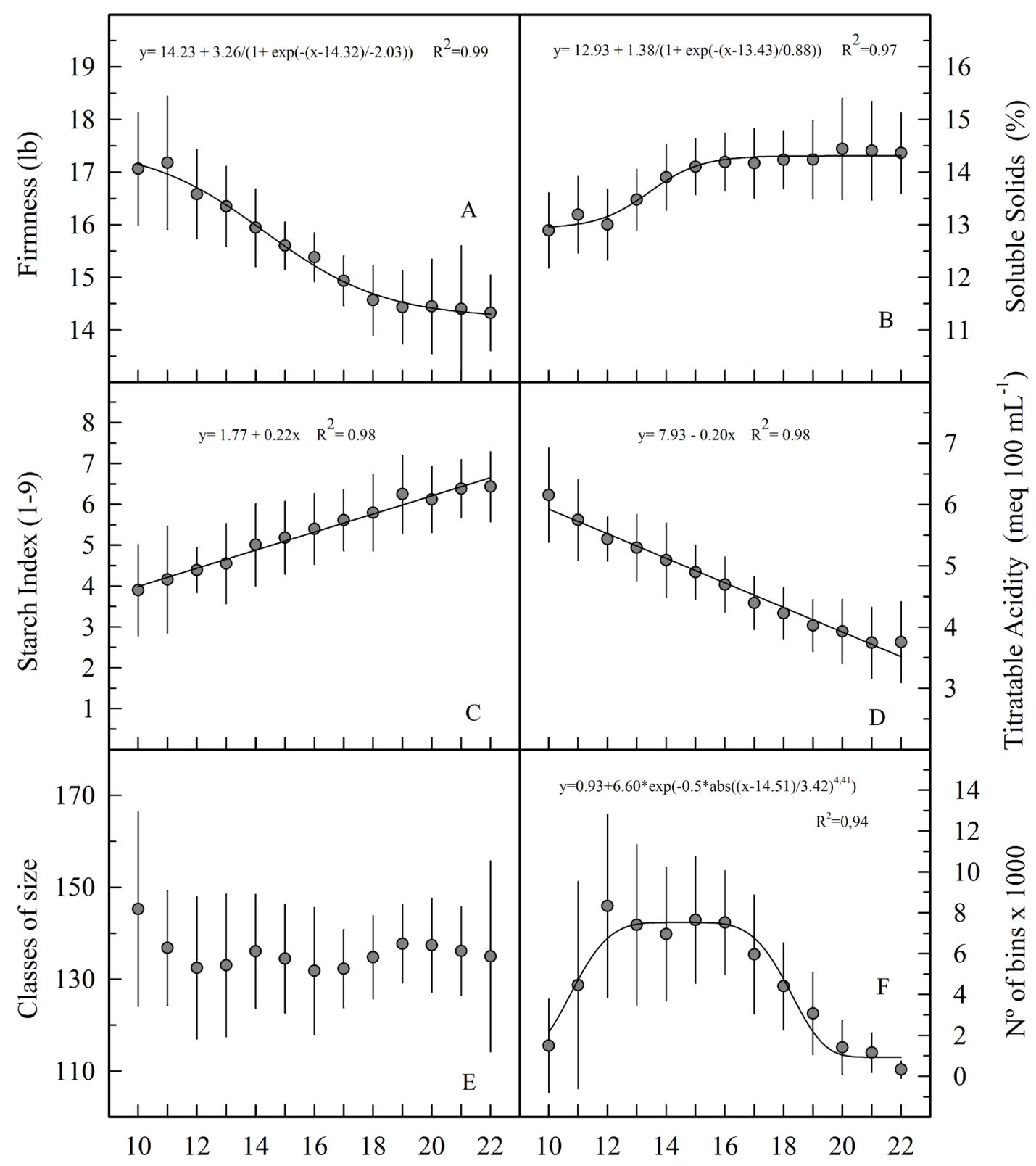

Harvest week of the year

FIGURE 2 - Firmness, soluble solids content, starch index, titratable acidity, class of fruit size and amount (number of bins) of 'Fuji' apple fruit received at warehouse as a function of harvest week of the year. The week 10 in the graphic means the tenth week of the year. Data represent averages of 11 years $(n=11)$. Vertical bars indicate the standard deviation among years. 


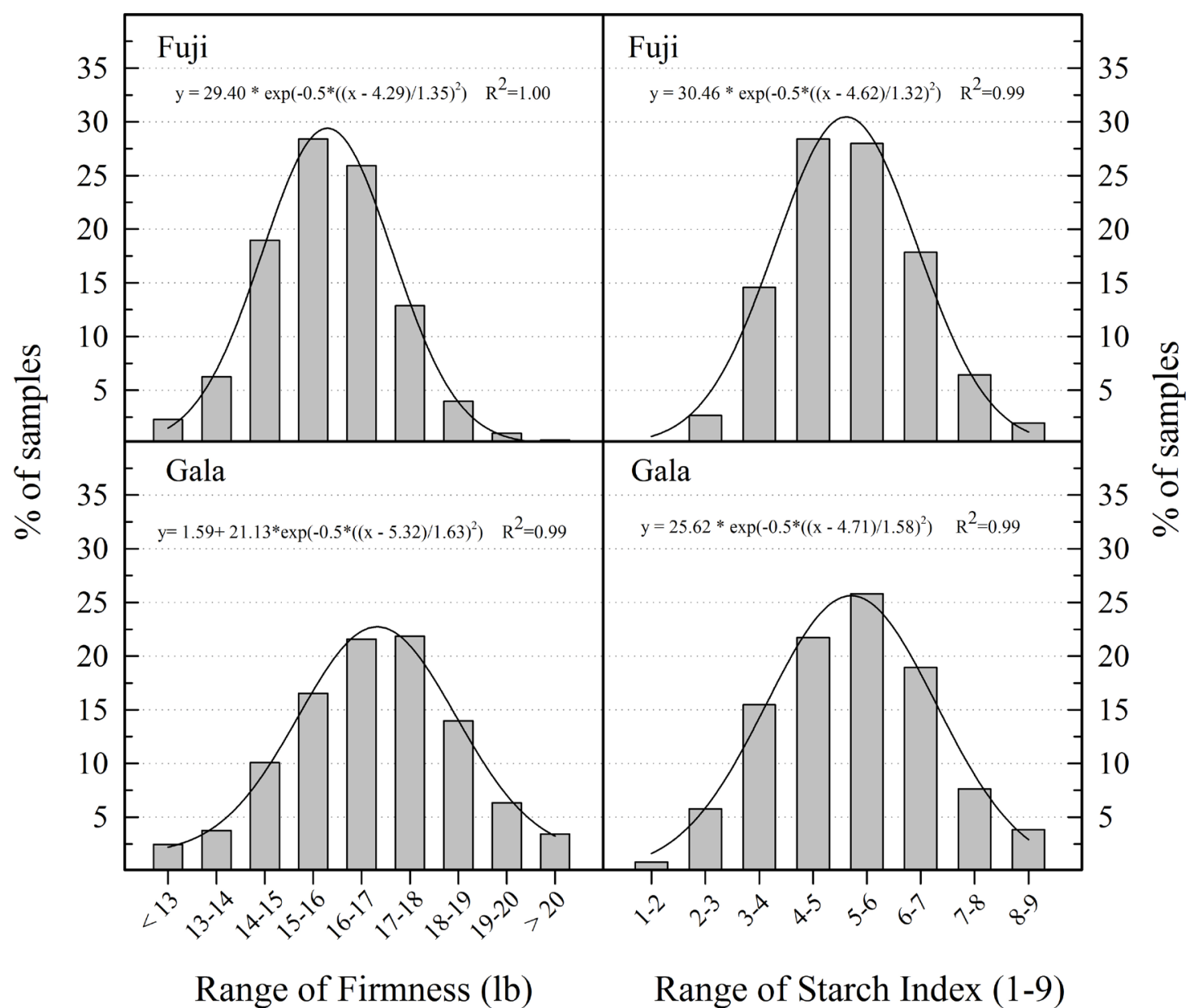

FIGURE 3 - Frequency of apple samples by range of apple fruit firmness and starch index at harvest. Mean data of 62,807 samples of 'Gala' apples fruit and 29,053 samples of 'Fuji' apple fruit analyzed over 11 years (2005 to 2015) at harvest. Each sample was composed of 100 apples. 


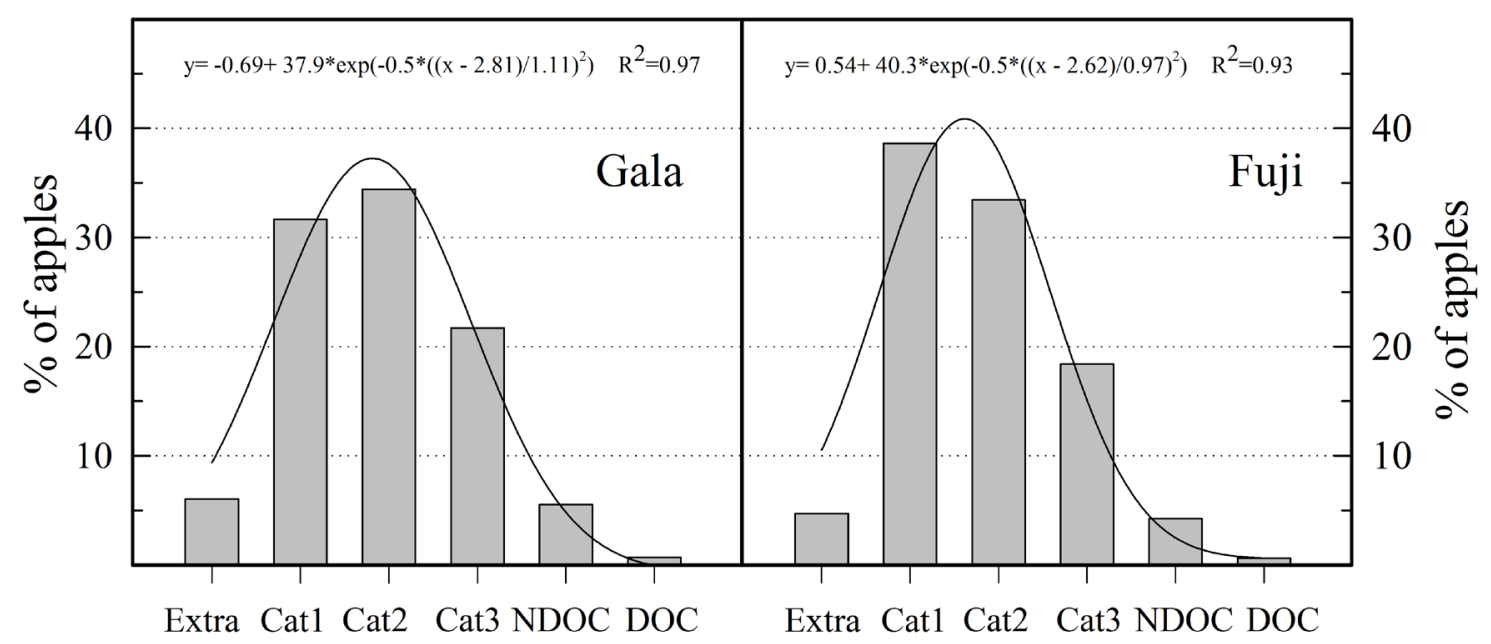

\section{Grades (Brazilian standard of quality)}

FIGURE 4 - Frequency of 'Gala' and 'Fuji' apple fruit grade (standard of quality) at harvest. Mean data of 62,807 samples 'Gala' apple fruit and 29,053 samples of 'Fuji' apple fruit analyzed over 11 years (2005 to 2015) at harvest. Each sample was composed of 100 apples. Extra fruit has the highest quality while DOC fruit has the least quality.

$\%$ of samples / Quality category

\section{CONCLUSIONS}

The frequencies (mean of 11 years) of apple fruit samples with storage potential for long, medium and short periods, based on the firmness measured at harvest, are $46 \%, 38 \%$ and $10 \%$ for 'Gala' and $44 \%$, $47 \%$ and $6.2 \%$ for 'Fuji', respectively.

The frequencies of apple fruit graded as Extra, Cat1, Cat2, Cat 3 and Out of Category are 6\%, $32 \%, 34 \%, 22 \%$ and $6 \%$, respectively, for 'Gala' and $5 \%, 39 \%, 33 \%, 18 \%, 5 \%$ for 'Fuji'.

From the first to the last week of harvest period, the apple fruit firmness vary from 17.9 to $14.2 \mathrm{lb}$ for 'Gala' and 17.1 to $14.3 \mathrm{lb}$ for 'Fuji'; the starch indices range from 4.0 to 6.1 for 'Gala' and 3.9 to 6.4 for 'Fuji'; the SS levels vary from 12.2 to $13.1 \%$ for 'Gala' and 12.9 to $14.4 \%$ for 'Fuji'; the TA ranges from 5.7 to 3.9 meq $100 \mathrm{~mL}^{-1}$ for 'Gala' and 6.2 to 3.8 meq $100 \mathrm{~mL}^{-1}$ for 'Fuji' (11-years means).

\section{ACKNOWLEDGMENTS}

To Fischer S/A Agroindustry for the support in the execution of this research and to Andreia M. T. Scolaro for data processing.

\section{REFERENCES}

ARGENTA, L.C. Concentração de etileno interno e maturação de maçãs cvs. Gala, Golden Delicious e Fuji. Revista Brasileira de Fruticultura, Jaboticabal, v.15, n.1, p.125-132, 1993.

ARGENTA, L.C. Fisiologia e tecnologia póscolheita: maturação, colheita e armazenagem dos frutos. In: EPAGRI. A cultura da macieira. Florianópolis, 2002. p.691-732.

ARGENTA, L.C.; BENDER, R.J.; KREUZ, C.L.; MONDARDO, M. Padrões de maturação e índices de colheita de maçãs cvs. Gala, Golden Delicious e Fuji. Pesquisa Agropecuária Brasileira, Brasília, DF, v.30, n.10, p.1259-1266, 1995.

ARGENTA, L.C.; MONDARDO, M. Maturação na colheita e qualidade de maçãs Gala após a armazenagem. Revista Brasileira de Fisiologia Vegetal, Campinas, v.6, n.2, p.135-140, 1994.

ARGENTA, L.C.; VIEIRA, M.J.; SCOLARO,A.M.T. Validação de catálogos de cores como indicadores do estádio de maturação e do ponto de colheita de maçã. Revista Agropecuária Catarinense, Florianópolis, v.23, n.3, p.71-77, 2010. 
BRASIL. Ministério da Agricultura, Pecuária e Abastecimento. Regulamento técnico de identidade e qualidade da maçã. Brasília, 2006. 9p. (Instrução Normativa, 5).

DE CASTRO, E.; BIASI, W.; MITCHAM, E.J. Quality of 'Pink Lady'apples in relation to maturity at harvest, pre-storage treatments, and controlled atmosphere during storage. Horticultural Science, Alexandria, v.42, n.3, p.605-610, 2007.

HARKER, F.R.; KUPFERMAN, E.M.; MARIN, A.B.; GUNSON, F.A.; TRIGGS, C.M. Eating quality standards for apples based on consumer preferences. Postharvest Biology and Technology, Amsterdam, v.50, n.1, p.70-78, 2008.

HARKER, F.R.; MAINDONALD, J.; MURRAY, S.H.; GUNSON, F.A.; HALLETT, I.C.; WALKER, S.B. Sensory interpretation of instrumental measurements 1: texture of apple fruit. Postharvest Biology and Technology, Amsterdam, v.24, n.1, p.225-239, 2002.

HAWERROTH, F.J.; PETRI, J.L.; LEITE, G.B.; COUTO, M. Uso de aminoetoxivinilglicina na maturação e queda pré-colheita de maçãs 'Imperial Gala'. Revista Ceres, Viçosa, MG, v.58, n.5, p.612618, 2011.

JEMRIĆ, T.; FRUK, I.; FRUK, M.; RADMAN, S.; SINKOVIČ, L.; FRUK, G. Bitter pit in apples: preand postharvest factors: A review. Spanish Journal of Agricultural Research, Madri, v.14, n.4, p.1-12, 2016.

LURIE, S.; WATKINS, C.B. Superficial scald, its etiology and control. Postharvest Biology and Technology, Amsterdam, v.65, n.1, p.44-60, 2012. PÉRÈS, P.N. O mercado mundial e nacional de maçã. In: ENCONTRO NACIONAL SOBRE FRUTICULTURA DE CLIMA TEMPERADO, 11, 2009, Fraiburgo. Palestras... Caçador: Epagri, 2009. p.117-126.
PETRI, J.L.; LEITE, G.B.; COUTO, M.; FRANCESCATTO, P. Avanços na cultura da macieira no Brasil. Revista Brasileira de Fruticultura, Jaboticabal, v.33, nesp, p.48-56, 2011.

PLOTTO, A.; AZARENKO, A.N.; MATTHEIS, J.P.; MCDANIEL, M.R. 'Gala', 'Braeburn' and 'Fuji' apples: maturity indices and quality after storage. Fruit Varieties Journal, University Park, v.49, n.3, p.133-142, 1995.

SCOLARO, A.M.; ARGENTA, L.C.; AMARANTE, C.V.T.; PETRI, J. L.; HAWERROTH, F.J. Controle da maturação pré-colheita de maçãs 'Royal Gala' pela inibição da ação ou síntese do etileno. Revista Brasileira de Fruticultura, Jaboticabal, v.37, n.1, p.38-47, 2015.

STANGER, M.C.; ARGENTA, L.C.; STEFFENS, C.A.; AMARANTE, C.V.T. Estádio de maturação para o período Ideal de colheita de maçãs 'Daiane' destinadas à armazenagem. Revista Brasileira de Fruticultura, Jaboticabal, v.35, n.4, p.977-989, 2013.

SYSTAT SOFTWARE. SigmaPlot for Windows Version 11.2. San Jose, 2011.

WATKINS, C. B.; ERKAN, M.; NOCK, J. F.; IUNGERMAN, K.A.; BEAUBRY, R.M.; MORAN, R.E. Harvest data effects on maturity, quality, and storage disorders of 'Honeycrisp' apples. HortScience, Salt Lake, v.40, n.1, p.164-169, 2005. 